NASA/CR-2001-210764

Heat Transfer and Flow on the Blade Tip of a Gas Turbine Equipped With a Mean-Camberline Strip

\author{
A.A. Ameri \\ AYT Corporation, Brook Park, Ohio
}


Since its founding, NASA has been dedicated to the advancement of aeronautics and space science. The NASA Scientific and Technical Information (STI) Program Office plays a key part in helping NASA maintain this important role.

The NASA STI Program Office is operated by Langley Research Center, the Lead Center for NASA's scientific and technical information. The NASA STI Program Office provides access to the NASA STI Database, the largest collection of aeronautical and space science STI in the world. The Program Office is also NASA's institutional mechanism for disseminating the results of its research and development activities. These results are published by NASA in the NASA STI Report Series, which includes the following report types:

- $\quad$ TECHNICAL PUBLICATION. Reports of completed research or a major significant phase of research that present the results of NASA programs and include extensive data or theoretical analysis. Includes compilations of significant scientific and technical data and information deemed to be of continuing reference value. NASA's counterpart of peerreviewed formal professional papers but has less stringent limitations on manuscript length and extent of graphic presentations.

- TECHNICAL MEMORANDUM. Scientific and technical findings that are preliminary or of specialized interest, e.g., quick release reports, working papers, and bibliographies that contain minimal annotation. Does not contain extensive analysis.

- CONTRACTOR REPORT. Scientific and technical findings by NASA-sponsored contractors and grantees.
- CONFERENCE PUBLICATION. Collected papers from scientific and technical conferences, symposia, seminars, or other meetings sponsored or cosponsored by NASA.

- SPECIAL PUBLICATION. Scientific, technical, or historical information from NASA programs, projects, and missions, often concerned with subjects having substantial public interest.

- TECHNICAL TRANSLATION. Englishlanguage translations of foreign scientific and technical material pertinent to NASA's mission.

Specialized services that complement the STI Program Office's diverse offerings include creating custom thesauri, building customized data bases, organizing and publishing research results ... even providing videos.

For more information about the NASA STI Program Office, see the following:

- Access the NASA STI Program Home Page at http://www.sti.nasa.gov

- E-mail your question via the Internet to help@sti.nasa.gov

- Fax your question to the NASA Access Help Desk at 301-621-0134

- Telephone the NASA Access Help Desk at 301-621-0390

- Write to:

NASA Access Help Desk

NASA Center for AeroSpace Information 7121 Standard Drive

Hanover, MD 21076 
NASA/CR-2001-210764

\title{
Heat Transfer and Flow on the Blade Tip of a Gas Turbine Equipped With a Mean-Camberline Strip
}

\author{
A.A. Ameri \\ AYT Corporation, Brook Park, Ohio
}

Prepared for the

2001 Summer Annual Gas Turbine Conference

sponsored by the American Society of Mechanical Engineers

New Orleans, Louisiana, June 3-7, 2001

Prepared under Contract NAS3-00180

National Aeronautics and

Space Administration

Glenn Research Center 


\section{Acknowledgments}

This work was sponsored by the Turbomachinery and Combustion Technology Project. The author wishes to express his gratitude to Dr. Raymond Gaugler, Chief of the Turbine Branch, for his support and encouragement of this work and Dr. R.S. Bunker for sharing of the experimental data and figures. Thanks are also due to my colleague Dr. Erlendur Steinthorsson for his reading and criticism of the manuscript. Some of the computations were performed on the CRAY-C90 of NAS at NASA Ames Research Center.

Available from

NASA Center for Aerospace Information 7121 Standard Drive

Hanover, MD 21076
National Technical Information Service 5285 Port Royal Road Springfield, VA 22100

Available electronically at http://gltrs.grc.nasa.gov/GLTRS 


\title{
Heat Transfer and Flow on the Blade Tip of a Gas Turbine Equipped with a Mean-Camberline Strip
}

\author{
A. A. Ameri \\ AYT Corporation \\ Brook Park, Ohio 44142 \\ ameri@grc.nasa.gov
}

\begin{abstract}
Experimental and computational studies have been performed to investigate the detailed distribution of convective heat transfer coefficients on the first-stage blade tip surface for a geometry typical of large power generation turbines(>100MW). In a previous work the numerical heat transfer results for a sharp edge blade tip and a radiused blade tip were presented. More recently several other tip treatments have been considered for which the tip heat transfer has been measured and documented. This paper is concerned with the numerical prediction of the tip surface heat transfer for radiused blade tip equipped with mean-camberline strip (or "squealer" as it is often called). The heat transfer results are compared with the experimental results and discussed. The effectiveness of the mean-camberline strip in reducing the tip leakage and the tip heat transfer as compared to a radiused edge tip and sharp edge tip was studied. The calculations show that the sharp edge tip works best (among the cases considered) in reducing the tip leakage flow and the tip heat transfer.
\end{abstract}

\section{NOMENCLATURE}

$C_{p} \quad$ constant pressure specific heat

$h \quad$ heat transfer coefficient

$\operatorname{Pr} \quad$ Prandtl number

$R \quad$ gas constant

Re Reynolds number

$T \quad$ static temperature/ $T_{0}$

$\mathrm{Tu} \quad$ turbulence intensity

$V \quad$ magnitude of the velocity/ $\left(R T_{0}\right)^{1 / 2}$

$y^{+} \quad$ dimensionless distance from a wall, $=y \frac{\sqrt{\tau_{w} / \rho}}{\nu}$

$\gamma \quad$ specific heat ratio

$\tau \quad$ shear stress

$$
\begin{array}{ll}
\text { Y } & \text { Total pressure loss, } \frac{P_{t_{0}}-P_{t_{1}}}{P_{t_{0}}-P_{1}} \\
\multicolumn{2}{l}{\text { Subscripts }} \\
\mathrm{t} & \text { total conditions } \\
\mathrm{W} & \text { wall value } \\
0 & \text { inlet condition } \\
1 & \text { exit conditions }
\end{array}
$$

\section{INTRODUCTION}

Blade tips are susceptible to burnout and oxidation due to high thermal loading caused by the tip leakage flow. Efficient internal or film cooling schemes are necessary to protect turbine blades against damage. The design of such schemes requires detailed knowledge of heating patterns on and near the tips which could be gained by experimental and predictive methods. It was shown by Mayle and Metzger [1] that the heat transfer at a blade tip (and by extension total pressure loss) is not very much affected by rotation. This has spurred experimental work on measuring tip heat transfer for various blade tip treatments on stationary cascades and has provided data for numerical simulations. In a previous numerical study [2] the predicted tip heat transfer for a sharp edge tip and a radiused tip (blade tip with a rounded edge around the perimeter of the blade tip) was compared with the measured experimental data of Bunker et al. [3]. The data was, at the time, the only set of liquid crystal measurements of tip heat transfer. The results of simulations nicely agreed with the experimental data and showed that the tip heat transfer for radiused edge would be larger than that for a sharp edge tip due to the relatively higher velocity on the radiused edge tip than on the sharp edge tip. More recently, Bunker and Bailey [4] have made further measurements for various tip treatments including circumferential rub strip, 45-degree angled run strips, perimeter squealer rim and mean-camberline strip. 


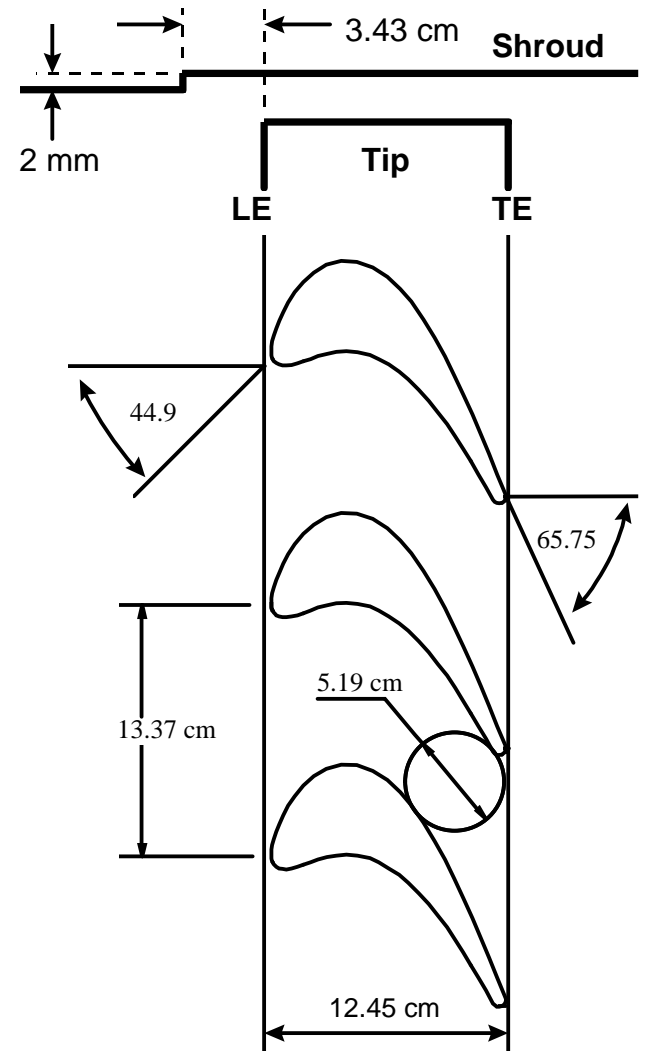

Fig. 1 Airfoil and shroud definition

The perimeter squealer tip case has already been computed by Ameri et al. [5] though for a different blade configuration. In this paper the mean-camberline strip (squealer) case has been computed. The computed tip heat transfer has been compared with experimental measurements. As the experiment was mainly concerned with the measurement of the rate of heat transfer, the numerical simulation attempts to construct the flow structure in order to help explain the phenomena observed in the experiments.

In the ensuing section a brief description of the experiment simulated in this work is provided. The numerical method employed and the grid topology used to model the computational domain are described subsequently. The results of the simulations showing the flow characteristics and computed tip leakage rate as well as the tip heat transfer are next presented and are followed by a summary and presentation of the conclusions of the work.

\section{THE EXPERIMENTAL SETUP}

The experimental setup and conditions are similar to those described in [3]. In that paper the pressure distribution and tip heat transfer for both a sharp edge tip and radiused edge tip of the present blade geometry were presented. The heat transfer measurement considered in this paper is for the same radiused edge blade in [3] but is equipped with a mean-camberline strip as given in Bunker and Bailey[4].

Figure 1 shows the definition of the airfoils and the shroud. The blade profiles are typical of a large power generation

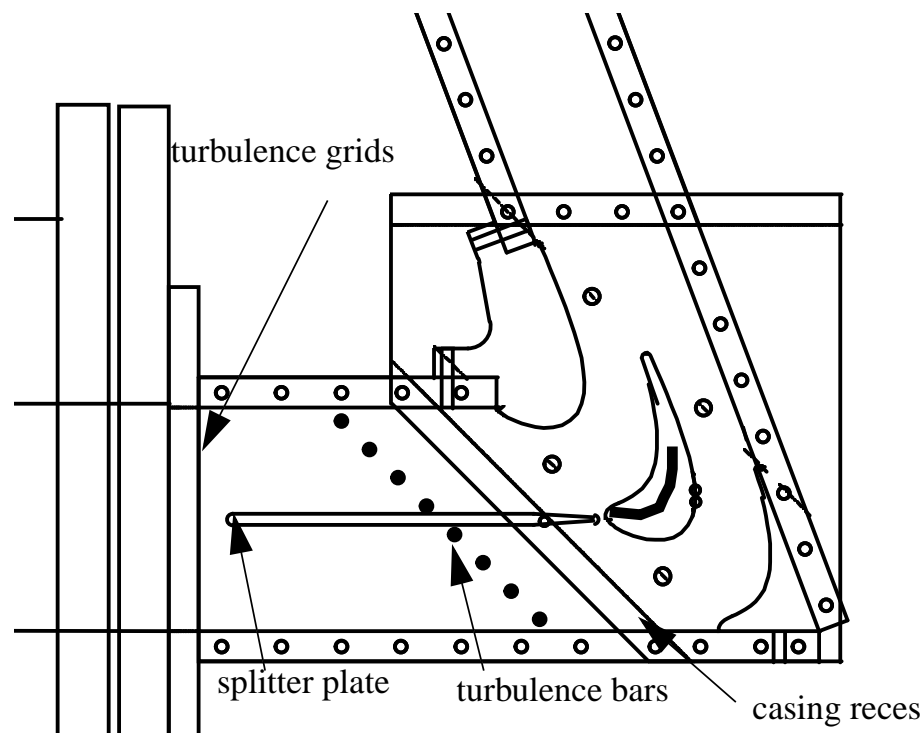

Fig. 2 Experimental rig

turbine. The cascade is linear and the span is $10.16 \mathrm{~cm}$. As can be seen the shroud incorporates a recess ahead of the blades to model a similar feature found in an actual turbine shroud. The instrumented blade has a rounded edge of $2.54-\mathrm{mm}$ radius. The tip clearance addressed in this paper is the nominal value of $2.03 \mathrm{~mm}$ measured from the top surface of the mean-camberline strip. The height of the mean-camberline strip was $1.27 \mathrm{~mm}$. This places the blade tip surface at $3.30 \mathrm{~mm}$ from the shroud (In [3] this distance was $2.03 \mathrm{~mm}$ ). The strip in the experiment and in the calculations has a square cross section and sharp edges. Figure 2 shows the design of the actual two passage blade cascade as reproduced from Bunker et al. [3]. The extent of the strip is from the leading edge to $85 \%$ axial chord. Table 1 lists the run conditions for the cascade and input to the numerical simulations.

\section{THE COMPUTATIONAL METHOD}

The simulations in this study were performed using a multiblock computer code called Glenn-HT [6] which is based on a single block code designed by Arnone et al. [7]. This code is a general purpose flow solver designed for simulations of flows in complicated geometries. The code solves the full compressible, Reynolds-averaged Navier-Stokes equations using a multi-stage Runge-Kutta based multigrid method. It uses the finite volume method to discretize the equations. The code uses central differencing together with artificial dissipation to discretize the convective terms. The overall accuracy of the code is second order. The present version of the code $[5,8,9]$ employs the $k-\omega$ turbulence model developed by Wilcox $[10,11]$ with modifications

TABLE 1: Run Conditions

\begin{tabular}{|l|l|}
\hline Pressure ratio across the blade row & 0.69 \\
\hline Exit Reynolds number & $2.57 \mathrm{E} 6$ \\
\hline Inlet Mach number & 0.30 \\
\hline Turbulence intensity & $5 \%$ \\
\hline Inlet angle & $44.9 \mathrm{deg}$. \\
\hline
\end{tabular}



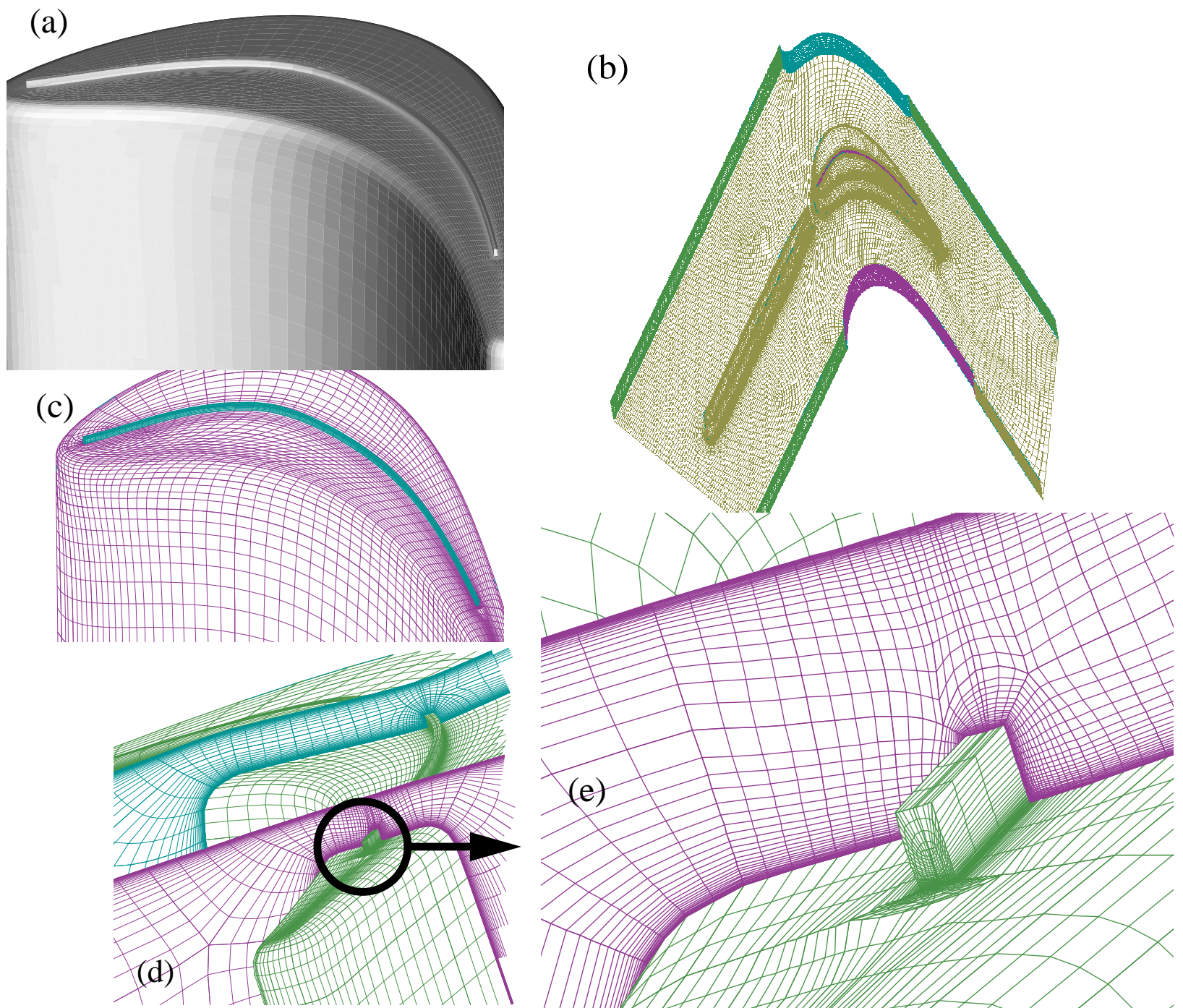

Fig. 3 Blade tip/passage and grid construction

(d)

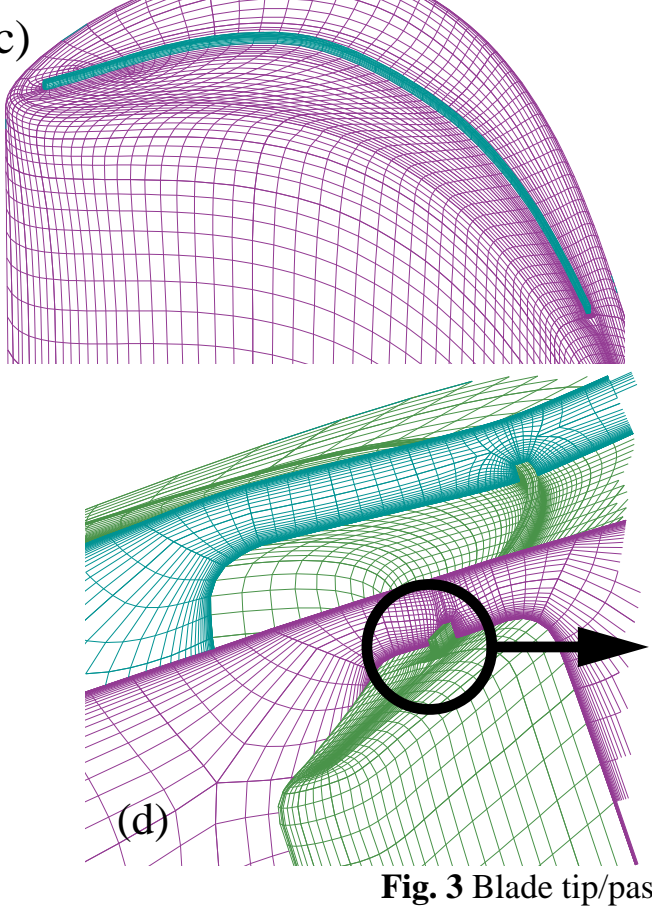

(c) by Menter [12]. The model integrates to the walls and no wall functions are used. For heat transfer a constant value of 0.9 for turbulent Prandtl number, $\mathrm{Pr}_{t}$ and a value for Prandtl number (Pr) equal to 0.72 is used. Viscosity is a function of temperature through a 0.7 power law [13] and $C p$ is taken to be a constant.

\section{GEOMETRY MODELING AND GRID SYSTEM}

As in [2] the complete two blade passage was modeled. This was done to achieve better agreement with the measured pressure distribution on the tip in the cited work. Figure 3(a) shows the blade surface and the modeled mean-camberline strip. Figure 3(b) (reproduced from [2]) shows the grid for the complete passage including the splitter plate. Figure 3(c) shows the surface grid on the blade tip with the radiused edge and the mean- camberline strip. The grid details on the tip including the mean-camberline strip is shown in figure 3(d). 3(e) shows further the details of the grid around the strip. The topology is designed such that the viscous gridlines stay near the surfaces (including the strip) and do not spread in the "inviscid" regions of the flow. The main differences between the present simulation and the actual geometry are twofold: The mean-camberline in the experiment is made up of piecewise straight lines and starts right at the leading edge whereas in the CFD simulation the strip is placed as a continuous strip and starts at a location 5\% of axial chord and not from the leading edge. This was done for practical grid generation reasons. The grid is generated using a commercially available computer program called GridPro ${ }^{\mathrm{TM}}$. The model of Fig. 3 consisted of 1.2 million cells when a a sharp edge tip was used. The number of cells were 1.4 million for the geometry with the radiused edge smooth tip. For the present case of a blade with a mean-camberline strip 1.8 million cells were used. The viscous grid is generated by embedding grid lines where needed, including the grid around the splitter. The stretching ratio did not exceed 1.25 for the viscous grid away from the no-slip surfaces. The distance to the first cell center adjacent to solid wall is such that the distance in wall units, $\left(\mathrm{y}^{+}\right)$is near or below unity. Specifically in the tip region the number of grid cells from the tip of the strip to the shroud was 50 and from 


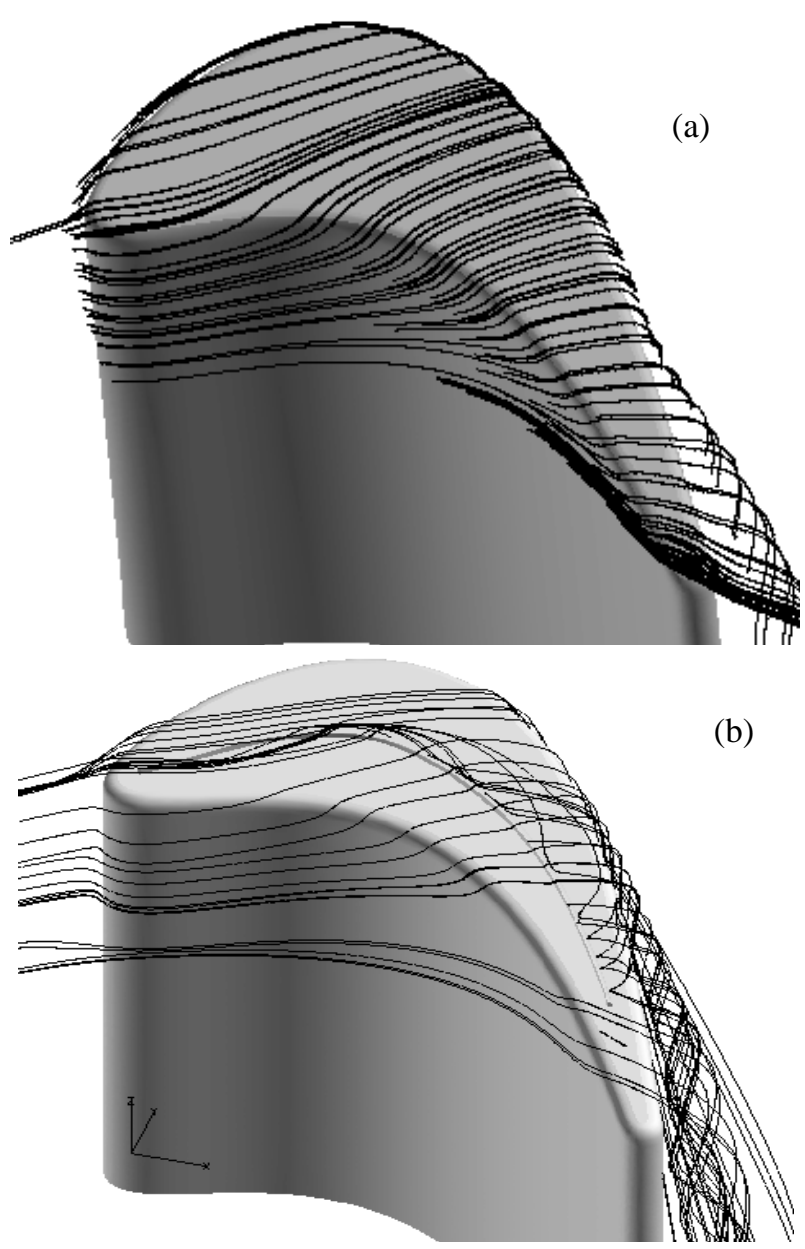

Fig. 4 Streamline patterns of the flow in the tip region for (a) radius edged tip (b) radius edged tip and meancamber line strip

the tip surface to the shroud was 58 cells. Further details about the grid may be found in [2].

\section{RESULTS AND DISCUSSION}

Along with the conditions given in Table 1 , a very thin boundary layer thickness of $0.1 \%$ of the passage height was imposed at the inlet to the computational domain upstream of the flow splitter (at the location of upstream turbulence grid in Fig. 2 ). The tunnel side walls were modeled using a slip boundary condition [2].

Figure 4 shows the streamline patterns of the flow in the tip clearance. Due to the rounded edge of the tip, the flow has little difficulty negotiating the turn into the clearance passage. In contrast on a sharp edge tip, a separation vortex forms along the pressure side edge of the blade tip thus narrowing the passage and thereby reducing the leakage[2]. Figure 4(b) shows the streamline pattern with the strip present. A separation vortex pattern behind the strip can be discerned from that figure. Figure 5 shows the pressure distribution over the blade tip. Note that the areas of low pressure are associated with high velocities. In Fig. 6 , the velocity vectors over the blade tip for several axial cross sections (Fig. 6(a)) and a plane parallel to tip at the half height of

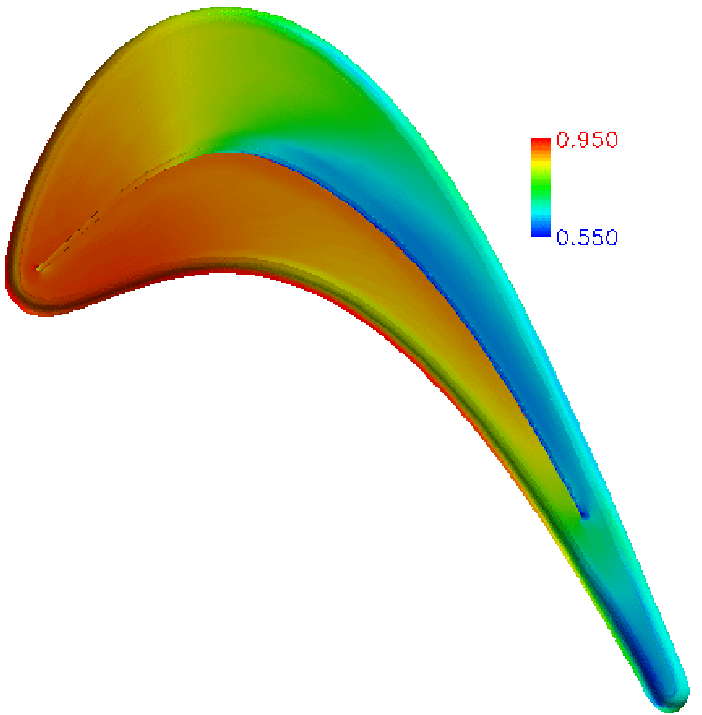

Fig. 5 Pressure distribution $\left(\mathrm{P}\right.$ static $\left./ \mathrm{P}_{0}\right)$ over the blade tip surface
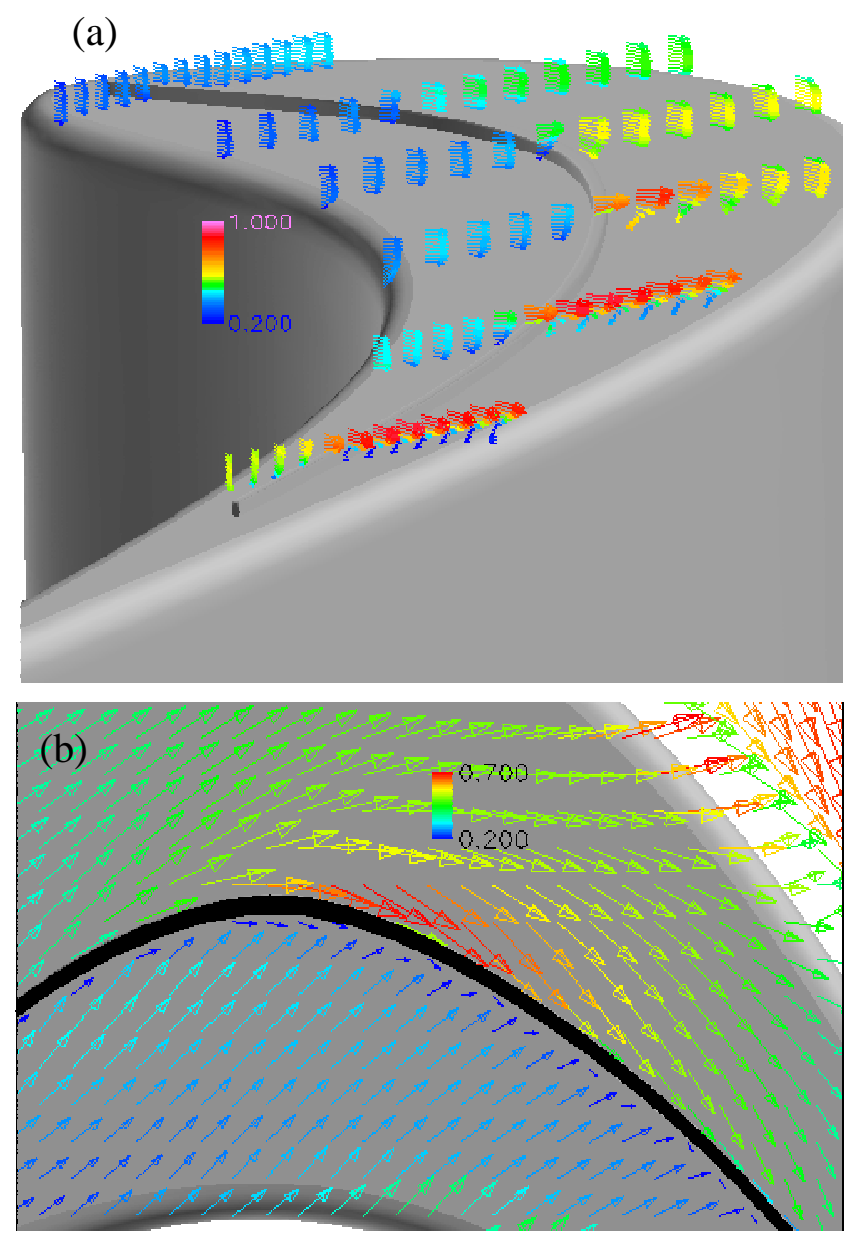

Fig. 6 Velocity vectors colored by the velocity magnitude $|\mathrm{V}|$. 


\begin{tabular}{|l|l|l|}
\hline \multicolumn{1}{|c|}{ Tip treatment } & \multicolumn{1}{c|}{$\begin{array}{c}\text { Percent } \\
\text { mass flow }\end{array}$} & Y \\
\hline Radiused edge & $2.5 \%$ & 0.118 \\
\hline Radiused edge+MCL Strip & $2.0 \%$ & 0.125 \\
\hline Sharp edge & $1.8 \%$ & 0.114 \\
\hline
\end{tabular}

TABLE 2: Tip leakage rates and total pressure losses

the strip are plotted (Fig. 6(b)). The figures show that the flow behind the strip possesses high velocity component parallel to the strip. It also shows that the velocity is reduced as the strip is approached. This flow pattern has implications for the blade tip heat transfer which will be discussed later in this paper.

\section{Tip leakage rate and efficiency comparisons}

Tip leakage flow rate is often a good indicator of tip losses and tip heat transfer in relation to different tip treatments. Usually the smaller the flow rate the lower the losses and smaller the tip heat transfer. Since it is difficult to measure the tip leakage flow rate, the computations can serve to provide such information as has been done here. Table 2 below shows the tip leakage as a fraction of the total mass flow into the blade passage. Note that the total mass flow is for two passages.

Table 2 shows that the mean-camberline strip reduces the tip leakage by $20 \%$ as compared to the radiused edge blade tip without the strip. Interestingly for a sharp edge tip with the same clearance, as shown in that table, the reduction in the leakage mass flow rate is $28 \%$. Also shown in Table 2 is the $\mathrm{Y}$ factor which is a measure of total pressure loss. The case with the mean-camberline strip although with lower tip leakage than the rounded case produces a larger loss. This also was the case with the squealer tip case of reference [5] where the reduction in leakage was not accompanied by a calculated improvement in efficiency.

\section{Heat Transfer}

The rate of heat transfer is presented in terms of heat transfer coefficient which is defined as:

$$
h=\frac{Q_{\text {wall }}}{\left(T_{\text {wall }}-T_{\text {inlet }}\right)}
$$

Tinlet is the inlet total temperature and $T_{\text {wall }}$ is the wall temperature. Twall was determined from the experimental measurements to be 1.06 times the inlet total temperature. The heat transfer coefficient was calculated on the blade tip where a constant temperature boundary condition is imposed. An effectively adiabatic boundary condition was imposed on all the other surfaces.

In Fig. 7, the radiused edge blade tip heat transfer is reproduced from [2]. The agreement between the experiment
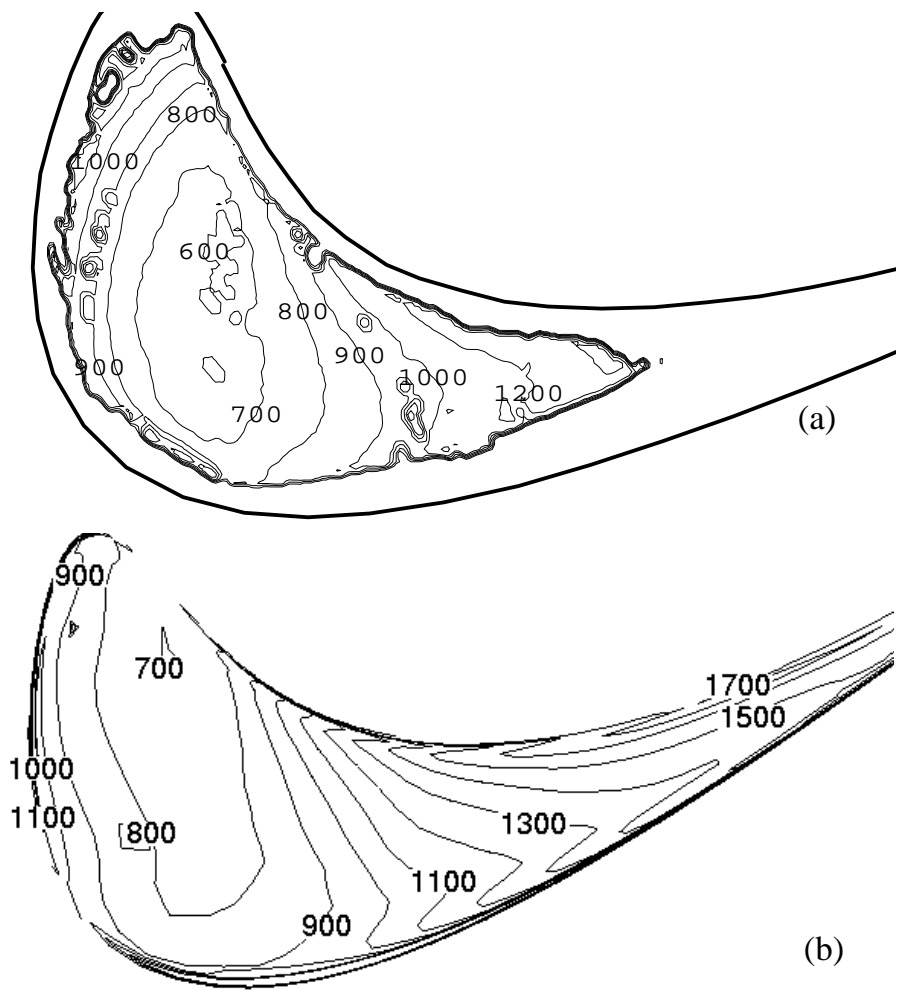

Fig. 7 Simple radiused edge blade tip. Heat transfer coefficient for $2.03 \mathrm{~mm}$ clearance and $\mathrm{Tu}=5 \%$. (W/m2/K),

(a) Measured (Bunker et al., 2000) and (b) calculated
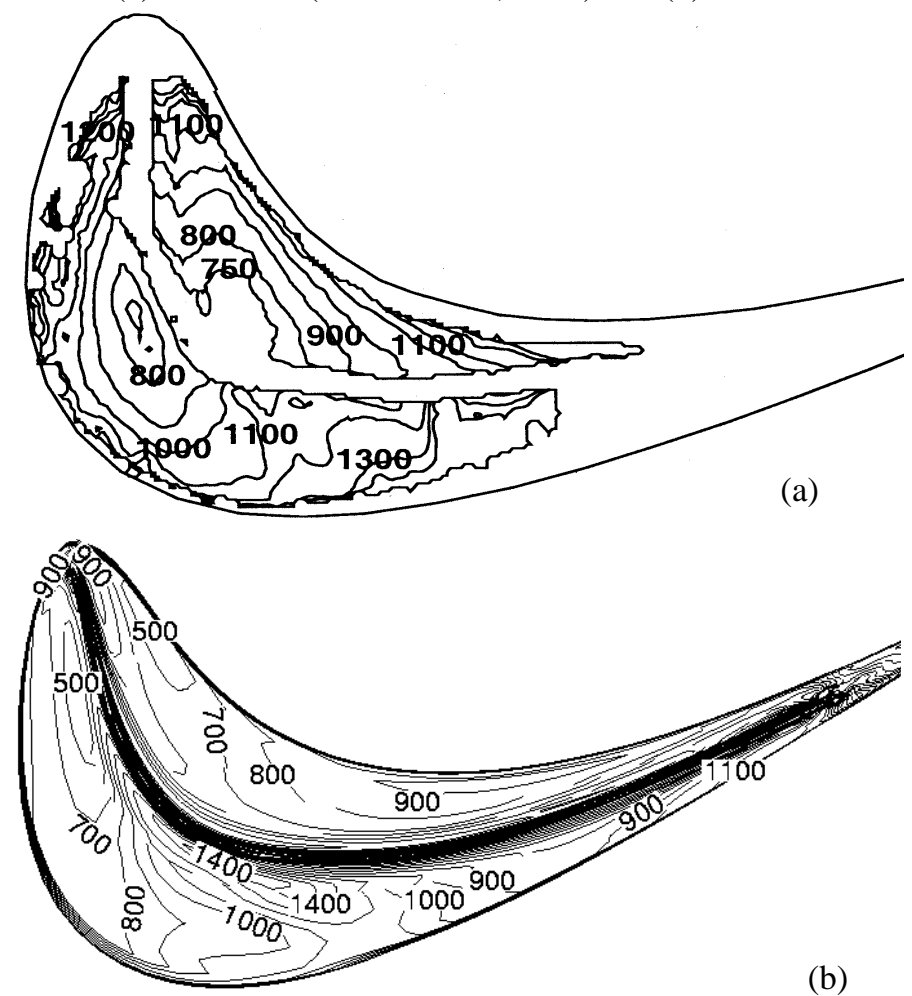

Fig. 8 Radiused edge blade tip with mean-camberline strip. Heat transfer coefficient for $2.03 \mathrm{~mm}$ clearance and $\mathrm{Tu}=5 \%$. (W/m2/ $\mathrm{K})$, (a) Measured (Bunker and Bailey, 2000) and (b) calculated 
and simulation for this case is consistently better than $15 \%$ over the entire tip. Figure 8 shows experimental and calculated tip heat transfer for the tip with the mean-camberline strip. The area of the largest heat transfer coefficient appears to be midchord near the suction side on the experiment and the simulation. Referring to Fig. 5, this area corresponds to the area of low surface pressure and thus high velocity over the blade tip. There are some discrepancies between the simulation and the experiment. They include the magnitude of the low island on the suction side near the strip and the apparent low value adjacent to the strip on the pressure side. These are likely caused by geometry differences between the model and the experiment discussed earlier or by the inadequacies of the turbulence model. The breakdown of the one-dimensional conduction assumption for the experimental data near the edges can also play a role in those differences. In the simulations the rate of heat transfer drops as the strip is approached on the pressure side of the strip and decreases away from the strip on the suction side. Figure 6 shows that the fluid velocity is diminished as it approaches the strip on the pressure side, this reduction in velocity reduces the heat convection to the blade. On the suction side of the strip there is a vortical zone within which the flow has a large velocity component parallel to the strip. This streamwise vortex continually feeds core temperature air to the blade tip, thus increasing the heat transfer. This accounts for the high heat transfer rate predicted by the numerical simulation.

It should be noted that without the mean-camberline strip, due to the increase in the clearance, the rate of heat transfer for the case of Fig. 8 would be larger than that of Fig. 7 for most of the blade tip surface except near the tail. The tail area in Fig. 6 does have a smaller rate of heat transfer. This has been reported in [14].

\section{SUMMARY AND CONCLUSIONS}

In this paper the numerical prediction of flow and heat transfer and comparison with the experimental heat transfer data of tip heat transfer for a blade equipped with a tip meancamberline strip (squealer) was performed. The blade chosen represents a first stage blade of a large power generation turbine. The casing upstream of the blade tip was recessed. The effect of mean-camberline strip on the tip leakage flow was quantified and compared to plain tip surfaces with radiused edge and sharp edges. It was found that the sharp edge works better than the radiused edge in reducing the tip leakage flow. For the radiused edge case it was found that the mean-camberline strip reduces the tip leakage but the total pressure loss is not commensurately reduced. Reasonably good comparison with the experimental heat transfer was achieved. Areas of large heat transfer rate were identified and likely reasons for local heat transfer enhancement was given using flow patterns.

\section{REFERENCES}

[1] Mayle, R. E. and Metzger, D. E., 1982, "Heat Transfer at the Tip of an Unshrouded Turbine Blade", Proc. Seventh Int. Heat Transfer Conf., Hemisphere Pub., pp. 87-92.

[2] Ameri, Ali A., and Bunker, R. S., 2000, "Heat Transfer and Flow on the First-Stage Blade Tip of a Power Generation Gas Turbine:Part 2-Simulation Results," Journal of Turbomachinery, Vol. 122. pp 272-277.

[3] Bunker, R.S., Bailey, J. C. and Ameri, Ali A., 2000., "Heat Transfer and Flow on the First-Stage Blade Tip of a Power Generation Gas Turbine:Part 1-Experimental Results,"Journal of Turbomachinery, Vol. 122. pp 263-271.

[4] Bunker, R.S. and Bailey, J. C., 2000, "An Experimental Study of Heat Transfer and Flow on a Gas Turbine Blade Tip with Various Tip Leakage Sealing Methods", Proceedings of the 4th ISHMT/ASME Heat and Mass Transfer Conference. Jan. 2000, India.

[5] Ameri, Ali A., and Steinthorsson, E., Rigby, David L., 1998, "Effect of Squealer Tip on Rotor Heat Transfer and Efficiency," Journal of Turbomachinery, Vol. 120. pp 753-759.

[6] Steinthorsson, E., Liou, M. S., and Povinelli, L.A., 1993, "Development of an Explicit Multiblock/Multigrid Flow Solver for Viscous Flows in Complex Geometries," AIAA-93-2380.

[7] Arnone, A., Liou, M.S., and Povinelli, L. A., 1991, "Multigrid Calculation of Three Dimensional Viscous Cascade Flows", AIAA Paper 91-3238.

[8] Rigby David, L., Ameri Ali, A. and Steinthorrson E., 1996, "Internal Passage Heat Transfer Prediction Using Multiblock Grids and k- $\omega$ Turbulence Model," IGTI paper 96GT-188.

[9] Rigby, D. L., Ameri A., A. and Steinthorrson E., 1997, "Numerical Prediction of Heat Transfer in a Channel with Ribs and Bleed," IGTI paper 97-GT-431.

[10] Wilcox, D. C., 1994a, Turbulence Modeling for CFD, DCW Industries, Inc. La Canada, CA.

[11] Wilcox, D. C., 1994b, "Simulation of Transition with a Two-Equation Turbulence Model," AIAA Journal, Vol. 32, No.2, pp. 247-255.

[12] Menter, Florian R., 1993, "Zonal Two-Equation k- $\omega$ Turbulence Models for Aerodynamic Flows," AIAA-93-2906.

[13] Schlichting, H. Boundary Layer Theory. McGraw-Hill, New York, seventh ed. pp. 312-313.

[14] Ameri, A. A., Steinthorsson, E. and Rigby, D. L. 1999, "Effects of Tip Clearance and Casing Recess on Heat Transfer and Stage Efficiency in Axial Turbines," Journal of Turbomachinery, Vol. 121. pp 683-693. 
Public reporting burden for this collection of information is estimated to average 1 hour per response, including the time for reviewing instructions, searching existing data sources, gathering and maintaining the data needed, and completing and reviewing the collection of information. Send comments regarding this burden estimate or any other aspect of this collection of information, including suggestions for reducing this burden, to Washington Headquarters Services, Directorate for Information Operations and Reports, 1215 Jefferson Davis Highway, Suite 1204, Arlington, VA 22202-4302, and to the Office of Management and Budget, Paperwork Reduction Project (0704-0188), Washington, DC 20503.

\begin{tabular}{|l|l|l}
\hline 1. AGENCY USE ONLY (Leave blank) & $\begin{array}{c}\text { 2. REPORT DATE } \\
\text { May } 2001\end{array}$ & $\begin{array}{c}\text { 3. REPORT TYPE AND DATES COVERED } \\
\text { Final Contractor Report }\end{array}$
\end{tabular}

4. TITLE AND SUBTITLE 5. FUNDING NUMBERS

Heat Transfer and Flow on the Blade Tip of a Gas Turbine Equipped With a Mean-Camberline Strip

6. AUTHOR(S)

WU-714-03-50-00

A.A. Ameri

NAS3-00180

7. PERFORMING ORGANIZATION NAME(S) AND ADDRESS(ES)

8. PERFORMING ORGANIZATION REPORT NUMBER

AYT Corporation

2001 Aerospace Parkway

E-12693

Brook Park, Ohio 44142

9. SPONSORING/MONITORING AGENCY NAME(S) AND ADDRESS(ES)

National Aeronautics and Space Administration

Washington, DC 20546-0001

10. SPONSORING/MONITORING AGENCY REPORT NUMBER

NASA CR-2001-210764

2001-GT-0156

\section{SUPPLEMENTARY NOTES}

Prepared for the 2001 Summer Annual Gas Turbine Conference sponsored by the American Society of Mechanical Engineers, New Orleans, Louisiana, June 3-7, 2001. Project Manager, R. Gaugler, Turbomachinery and Propulsion Systems Division, NASA Glenn Research Center, organization code 5820, 216-433-5882.

12a. DISTRIBUTION/AVAILABILITY STATEMENT

12b. DISTRIBUTION CODE

Unclassified - Unlimited

Subject Categories: 02 and 34

Distribution: Nonstandard

Available electronically at http://gltrs.grc.nasa.gov/GLTRS

This publication is available from the NASA Center for AeroSpace Information, 301-621-0390.

13. ABSTRACT (Maximum 200 words)

Experimental and computational studies have been performed to investigate the detailed distribution of convective heat transfer coefficients on the first-stage blade tip surface for a geometry typical of large power generation turbines (>100 MW). In a previous work the numerical heat transfer results for a sharp edge blade tip and a radiused blade tip were presented. More recently several other tip treatments have been considered for which the tip heat transfer has been measured and documented. This paper is concerned with the numerical prediction of the tip surface heat transfer for radiused blade tip equipped with mean-camberline strip (or "squealer" as it is often called). The heat transfer results are compared with the experimental results and discussed. The effectiveness of the mean-camberline strip in reducing the tip leakage and the tip heat transfer as compared to a radiused edge tip and sharp edge tip was studied. The calculations show that the sharp edge tip works best (among the cases considered) in reducing the tip leakage flow and the tip heat transfer.

\section{SUBJECT TERMS}

Turbomachinery; Gas turbine; Turbine heat transfer; Modeling; Blade Tip 15. NUMBER OF PAGES 12

\begin{tabular}{|c|c|c|}
\hline $\begin{array}{c}\text { 17. SECURITY CLASSIFICATION } \\
\text { OF REPORT } \\
\text { Unclassified }\end{array}$ & $\begin{array}{c}\text { 18. SECURITY CLASSIFICATION } \\
\text { OF THIS PAGE } \\
\text { Unclassified }\end{array}$ & $\begin{array}{c}\text { 19. SECURITY CLASSIFICATION } \\
\text { OF ABSTRACT } \\
\text { Unclassified }\end{array}$ \\
\hline
\end{tabular}

